\title{
Dexmedetomidine sedation in painful posterior segment surgery
}

This article was published in the following Dove Press journal:

Clinical Ophthalmology

12 December 2012

Number of times this article has been viewed

\author{
Ahmad Mansour ${ }^{1,2}$ \\ Samar Taha ${ }^{3}$ \\ 'Department of Ophthalmology, \\ American University of Beirut, \\ Beirut, Lebanon; ${ }^{2}$ Rafik Hariri \\ University Hospital, Beirut, Lebanon; \\ ${ }^{3}$ Department of Anesthesiology, \\ American University of Beirut, Beirut, \\ Lebanon
}

Purpose: To present a case series on the use of dexmedetomidine (Precedex) sedation in painful posterior segment surgery performed under topical anesthesia, similar to its use in cataract surgery.

Methods: A prospective review of cases that had posterior segment surgery under topical anesthesia and that needed sedation. Dexmedetomidine-loading infusion was $1 \mathrm{mcg} / \mathrm{kg}$ over 10 minutes, followed by a maintenance infusion $(0.5 \mathrm{mcg} / \mathrm{kg} / \mathrm{h})$.

Results: Nine patients were operated on under topical anesthesia: two scleral buckle, five cryopexy, one scleral laceration, and one pars plana vitrectomy with very dense laser therapy in an albinotic fundus; six patients had retinal detachment. General or local anesthesia were not possible due to medical or ocular morbidities, use of anticoagulants, or the surgery plan changed intraoperatively when new pathologies were discovered. The surgeon achieved good surgical control in eight of nine cases, with one patient having ocular and bodily movements that were disturbing. Six patients had no pain, while three patients reported mild pain. No adverse effects were noted and all patients had successful surgical outcomes. Heart rate, blood pressure, and oxygen saturation were well controlled throughout the procedures. The most frequent adverse reactions of dexmedetomidine reported in the literature in less than 5\% (hypotension, bradycardia, and dry mouth) were not recorded in the present study.

Conclusion: When a surgeon has planned to do a pars plana vitrectomy under topical anesthesia and the surgical situation dictates the addition of cryopexy, scleral buckle, or intense laser retinopexy, then sedation with dexmedetomidine can help in the control of ocular pain in the majority of cases, with good intraoperative and immediate postoperative hemodynamic control with the possibility of supplemental rescue analgesia. Dexmedetomidine, a sedative analgesic, is devoid of respiratory depressant effects, and its use in posterior segment surgery under topical anesthesia is reported here for the first time.

Keywords: dexmedetomidine, vitreoretinal surgery, topical anesthesia

\section{Summary statement}

Dexmedetomidine (Precedex, Hospira Japan Co, Ltd), a sedative analgesic, is devoid of respiratory depressant effects and its use in posterior segment surgery is reported here in subjects undergoing vitreoretinal surgery under topical anesthesia. The surgeon achieved good surgical control in eight of nine patients. Pain was absent in six of nine patients and mild in three of nine patients. No adverse effects were noted and the patients had successful surgical outcomes. Heart rate, blood pressure, and oxygen saturation were well controlled throughout the procedures.
Correspondence: Ahmad Mansour Department of Ophthalmology, American University of Beirut, POB I I3-6044, Beirut, Lebanon Tel +96| I 374625

Email ammansourmd@gmail.com 


\section{Introduction}

Dexmedetomidine is an alpha2-adrenergic agonist and produces sedative-hypnotic, analgesic, and anxiolytic effects by an action on alpha2-receptors in the locus ceruleus. ${ }^{1}$ It has been approved for use in intensive care units. When used for intraoperative sedation, dexmedetomidine has a slower onset than propofol but has similar cardiorespiratory side effects. ${ }^{2}$ Similar sedative effects to midazolam were found in a double-blind study in patients undergoing cataract surgery, with more effective lowering of intraocular pressure in the dexmedetomidine group. ${ }^{3}$ Its indication in the United States was recently expanded to include patients requiring sedation for short procedures ${ }^{2}$ or as

Table I Clinical profile of patients receiving dexmedetomidine sedation under topical anesthesia

\begin{tabular}{|c|c|c|c|c|c|c|c|}
\hline $\begin{array}{l}\text { Patient number: reason } \\
\text { for dex sedation under TA }\end{array}$ & Age & $\mathbf{M} / \mathbf{F}$ & Operation & $\begin{array}{l}\text { Duration } \\
\text { of surgery } \\
(\mathrm{min})\end{array}$ & $\begin{array}{l}\text { Pain } \\
\text { score }\end{array}$ & $\begin{array}{l}\text { Surgeon } \\
\text { comfort }^{\mathrm{a}}\end{array}$ & $\begin{array}{l}\text { HR in } \\
\text { OR }\end{array}$ \\
\hline $\begin{array}{l}\text { NI: Patient refused GA; very } \\
\text { deep-set eyeball; tight orbit }\end{array}$ & 54 & M & $S B$ for $R D$ & 90 & 2 & 3 & 65 \\
\hline $\begin{array}{l}\text { N2: Patient ate a meal just } \\
\text { before scheduled GA; } \\
\text { very tight orbit }\end{array}$ & 51 & $\mathrm{~F}$ & $S B$ for $R D$ & 120 & 2 & 2 & 80 \\
\hline $\begin{array}{l}\text { N3: During PPV, dialysis was } \\
\text { noted and treated with cryo }\end{array}$ & 26 & M & $\begin{array}{l}\text { PPV with internal limiting membrane } \\
\text { peel, endolaser, and cryo for RD } \\
\text { from retinal dialysis }\end{array}$ & 120 & 2 & 2 & 80 \\
\hline $\begin{array}{l}\text { N4: RD was detected } \\
\text { intraoperatively }\end{array}$ & 64 & M & $\begin{array}{l}\text { Cryo after PPV for vitreous } \\
\text { hemorrhage. Peripheral flat } \\
\text { RD detected intraoperatively }\end{array}$ & 45 & 0 & 3 & 60 \\
\hline $\begin{array}{l}\text { N5: Very deep-set eyeball; tight } \\
\text { orbit; RBA would jeopardize } \\
\text { already poor retinal circulation } \\
\text { and increase further intraocular } \\
\text { pressure }\end{array}$ & 60 & $\mathrm{~F}$ & $\begin{array}{l}\text { Cryo to retina and ciliary body } \\
\text { for neovascular glaucoma with } \\
\text { severe proliferative diabetic } \\
\text { retinopathy and miotic pupil }\end{array}$ & 30 & 0 & 3 & 90 \\
\hline $\begin{array}{l}\text { N6: The eye needed very } \\
\text { high laser energy setting } \\
\text { because of albinotic fundus }\end{array}$ & 55 & M & $\begin{array}{l}\text { PPV for RD repair from giant } \\
\text { retinal tear }\end{array}$ & 90 & 0 & 3 & 90 \\
\hline $\begin{array}{l}\text { N7: Patient had open globe } \\
\text { and ate just before surgery }\end{array}$ & 40 & M & $\begin{array}{l}\text { Suturing of scleral laceration } \\
\text { with uveal prolapse }\end{array}$ & 30 & 2 & $\begin{array}{l}\text { I } \\
\text { Severe Bell's } \\
\text { phenomenon, } \\
\text { continuous ocular } \\
\text { and bodily movements }\end{array}$ & 70 \\
\hline N8: Patient refused RBA & 17 & M & $\begin{array}{l}\text { Cryo for exudative RD from } \\
\text { Coats' disease }\end{array}$ & 15 & 0 & 3 & 80 \\
\hline $\begin{array}{l}\text { N9: Patient refused RBA } \\
\text { because of anticoagulant } \\
\text { therapy }\end{array}$ & 40 & M & $\begin{array}{l}\text { Cryo of ciliary body for traumatic } \\
\text { glaucoma following traumatic } \\
\text { RD repair }\end{array}$ & 45 & 0 & 3 & 70 \\
\hline Total/mean & 47 & $7 \mathrm{M} / 2 \mathrm{~F}$ & $\begin{array}{l}\mathrm{SB}, 2 \\
\text { cryo, 8; } \\
\text { sclera laceration, I }\end{array}$ & 77 & 1.3 & 2.4 (good) & 72.1 \\
\hline
\end{tabular}

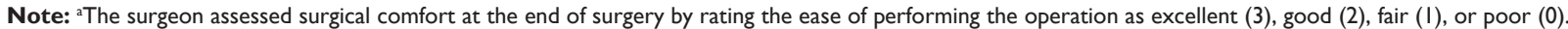
Abbreviations: BP, blood pressure; cryo, cryopexy; dex, dexmedetomidine; F, female; GA, general anesthesia; HR, heart rate; M, male; min, minutes; O2 sat, oxygen saturation; OR, operating room; PPV, pars plana vitrectomy; RBA, retrobulbar anesthesia; RD, retinal detachment; RR, recovery room; SB, scleral buckle; TA, topical anesthesia. 
an adjunct for general anesthesia without undue hemodynamic fluctuation and with a decrease in the excitatory response during extubation. In ophthalmology, dexmedetomidine has been used in patients undergoing cataract surgery under local ${ }^{3-5}$ or topical anesthesia, ${ }^{6,7}$ various ocular surgeries under general anesthesia, ${ }^{8}$ and retinal surgeries under general anesthesia. ${ }^{9}$ We present our experience with the medication in painful posterior segment surgery performed under topical anesthesia.

\section{Methods}

This study performed a prospective review of cases with painful posterior segment surgery under topical

\begin{tabular}{|c|c|c|c|c|c|c|c|c|}
\hline $\begin{array}{l}\text { BP in } \\
\text { OR }\end{array}$ & $\begin{array}{l}\text { O2 sat with } \\
\text { intranasal } \\
\text { O2 in OR }\end{array}$ & $\begin{array}{l}\text { Duration of stay } \\
\text { in RR before } \\
\text { discharge (min) }\end{array}$ & $\begin{array}{l}\text { HR in } \\
\mathbf{R R}\end{array}$ & $\begin{array}{l}\text { BP in } \\
\mathbf{R R}\end{array}$ & $\begin{array}{l}\text { O2 sat } \\
\text { In } R R \text { under } \\
\text { room air }\end{array}$ & $\begin{array}{l}\text { Pain score } \\
\text { in } \mathbf{R} \mathbf{R}\end{array}$ & $\begin{array}{l}\text { RSS score in } \\
\text { OR and RR }\end{array}$ & $\begin{array}{l}\text { Outcome and use } \\
\text { of other sedatives }\end{array}$ \\
\hline $110 / 60$ & 98 & 90 & 67 & I I0/80 & 98 & $\begin{array}{l}0 / 10 \\
\text { (Initial 4/10 } \\
\text { relieved by } \\
\text { iv perfalgan) }\end{array}$ & 2 & $\begin{array}{l}\text { Flat retina; } \\
\text { fentanyl } 25 \mathrm{mcg} \text { and } \\
\text { midazolam } 0.5 \mathrm{mg} \text { were } \\
\text { given I hour after surgery } \\
\text { to prevent pain }\end{array}$ \\
\hline $130 / 65$ & 100 & 120 & 76 & $120 / 70$ & 98 & $2 / 10$ & 2 & $\begin{array}{l}\text { Flat retina; } \\
\text { fentanyl } 50 \text { mcg given } \\
\text { initially but was insufficient } \\
\text { and, I } 5 \text { min later, dex was } \\
\text { started }\end{array}$ \\
\hline $120 / 60$ & 100 & 30 & 70 & I I5/75 & 97 & $0 / 10$ & 2 & $\begin{array}{l}\text { Flat retina; } \\
\text { fentanyl } 50 \text { mg given at } \\
\text { start of cryo, } 15 \text { min } \\
\text { before end of procedure }\end{array}$ \\
\hline $140 / 75$ & 98 & 30 & 70 & |45/75 & 97 & $0 / 10$ & 2 & Flat retina \\
\hline $140 / 90$ & 100 & 90 & 78 & $130 / 80$ & 100 & 0 & 2 & $\begin{array}{l}\text { Intraocular pressure } \\
\text { dropped from } 55 \mathrm{mmHg} \\
\text { to } 18 \mathrm{mmHg}\end{array}$ \\
\hline I I5/70 & 100 & 15 & 76 & $110 / 60$ & 100 & $0 / 10$ & 2 & $\begin{array}{l}\text { Flat retina; dex was used } \\
\text { after fentanyl } 50 \text { mcg failed } \\
\text { to control the pain }\end{array}$ \\
\hline $150 / 75$ & 100 & 45 & 78 & $120 / 70$ & 100 & 0 & 2 & Stable \\
\hline $160 / 80$ & 99 & 60 & 100 & $120 / 70$ & 99 & 0 & 2 & Flat retina \\
\hline $120 / 85$ & 100 & 60 & 82 & I I5/60 & 99 & $0 / 10$ & 2 & $\begin{array}{l}\text { Recurrent glaucoma } \\
4 \text { months postoperatively; } \\
\text { fentanyl } 50 \text { mcg failed to } \\
\text { control pain, and, I } 5 \text { min } \\
\text { later, dex was started }\end{array}$ \\
\hline $126 / 70$ & 99.4 & 55.7 & 74 & I I9/70 & 98.4 & $0 / 10$ & 2 & $\begin{array}{l}\text { Two had other sedative } \\
\text { prior to dex sedation; } \\
\text { three needed sedatives } \\
\text { during dex sedation; } \\
\text { and two did not need } \\
\text { additional sedatives }\end{array}$ \\
\hline
\end{tabular}


anesthesia (Xylocaine [lidocaine hydrogen chloride] 2\% Jelly, AstraZeneca, London, UK) that required sedation. Dexmedetomidine-loading infusion was $1 \mathrm{mcg} / \mathrm{kg}$ over 5 to 10 minutes, followed by a maintenance infusion of $0.5 \mathrm{mcg} /$ $\mathrm{kg} / \mathrm{h}$ throughout the surgery using an infusion pump. Additional analgesia, such as cryopexy, was requested by the surgeon during potentially painful steps of the surgery or if the patient expressed pain. Antiemetic therapy (ondansetron hydrochloride [Zofran; GlaxoSmithKline, Middlesex, UK] and metoclopramide [Primperan; Sanofi Aventis, Little Rock, AK, USA]) was given routinely to all patients undergoing scleral buckle surgery. The study was approved by the Institutional Review Board (Rafik Hariri University Hospital, affiliate American University of Beirut, Beirut, Lebanon). Primary outcome measures were patient sedation comfort, pain perception, stability of vital signs, and surgeon satisfaction.

Pain score was assessed in the operating room by the surgeon at the end of surgery. Pain score in the recovery room was graded routinely by a registered nurse with a visual analog scale of zero to ten. The Ramsay sedation scale score is a commonly used subjective assessment of level of consciousness that uses an ordinal scaling system to describe the level of consciousness: level 1: awake, anxious/restless; level 2: awake, cooperative; level 3: awake, responds to commands only; level 4: asleep, brisk response to loud auditory stimulus; level 5: asleep, sluggish response to loud auditory stimulus; level 6: asleep, no response to loud auditory stimulus. ${ }^{10}$ The Ramsay sedation scale score is routinely assessed in our center by an anesthesiologist intraoperatively and by a registered nurse in the recovery room. The surgeon assessed surgical comfort at the end of surgery by rating the ease of performing the operation as excellent (score of 3 ), good (2), fair (1), or poor (0).

\section{Results}

Nine patients were operated on under topical anesthesia. Operations comprised two scleral buckles, five cryopexys, one scleral laceration, and one pars plana vitrectomy with very dense laser therapy in an albinotic fundus. Six patients had retinal detachment (Table 1). General or local anesthesia were not possible due to medical problems (cardiovascular insufficiency); ocular problems (retrobulbar anesthesia could cause poor circulation in a subject with neovascular glaucoma); bleeding tendency from use of anticoagulants; patient refusal of retrobulbar injections; or if the surgery plan changed intraoperatively when new pathologies were discov- ered. The surgeon achieved good surgical control (ability to complete surgery) in eight cases (as assessed at the end of surgery); a single patient demonstrated ocular and bodily movements. Four patients had no pain, while three patients reported mild pain. We added supplemental sedatives (rescue analgesics) on the surgeon's request during the most painful part of the surgical intervention to avoid pain (Table 1). No adverse effects were noted and the patients had successful surgical outcomes. Heart rate, blood pressure, and oxygen saturation were within the normal range before surgery and were well controlled throughout the procedures and in the recovery room. The most frequent adverse reactions of dexmedetomidine reported in the literature in less than $5 \%$ (hypotension, bradycardia, and dry mouth) were not recorded in the present study (Table 1).

\section{Discussion}

Surgeon satisfaction and comfort were subjectively good. Pain scores were low and patients were cooperative throughout the procedures. Vital signs were stable in the operating room and in the recovery room. The current patient series is biased toward a younger population and includes a small number of subjects. The ability of the surgeon to perform scleral buckle and retinal cryopexy procedures under topical anesthesia attests to the efficiency of the drug in providing safe, awake sedation and analgesia. ${ }^{11}$ The intraocular pressure lowering effect of dexmedetomidine ${ }^{3,4}$ facilitates the treatment of open globes under dexmedetomidine, and we treated one patient accordingly (Table 1). Unlike in the findings of Alhashemi, ${ }^{5}$ the use of dexmedetomidine did not prolong the recovery period. Two patients with scleral buckle and cryopexy experienced pain in the recovery room - a result that is frequently reported after such procedures.

\section{Conclusion}

Dexmedetomidine provides satisfactory sedation during posterior segment surgery, similar to its use in anterior segment surgery, ${ }^{7}$ with good patient cooperation, which provides adequate operating conditions for surgeons and acceptable surgical outcomes without adverse side effects in eyes under topical anesthesia. When a surgeon has planned to do a pars plana vitrectomy under topical anesthesia and the surgical situation dictates the addition of cryopexy; or has planned to perform a scleral buckle or intense laser retinopexy, then sedation with dexmedetomidine can help control ocular pain in the majority of cases. 


\section{Disclosure}

The authors report no conflicts of interest in this work.

\section{References}

1. Apan A, Doganci N, Ergan A, Büyükkoçak U. Bispectral indexguided intraoperative sedation with dexmedetomidine and midazolam infusion in outpatient cataract surgery. Minerva Anestesiol. 2009;75: 239-244.

2. Aantaa RE, Kanto JH, Scheinin M, Kallio AM, Scheinen H. Dexmedetomidine premedication for minor gynecologic surgery. Anesth Analg. 1990;70:407-413.

3. Virkkilä M, Ali-Melkkilä T, Kanto J, Turunen J, Scheinin H. Dexmedetomidine as intramuscular premedication for day-case cataract surgery. A comparative study of dexmedetomidine, midazolam, and placebo. Anaesthesia. 1994;49:853-858.

4. Ayoglu H, Altunkaya H, Ozer Y, et al. Dexmedetomidine sedation during cataract surgery under regional anaesthesia. Br J Anaesth. 2007;99:448.

5. Alhashemi JA. Dexmedetomidine vs midazolam for monitored anaesthesia care during cataract surgery. Br J Anaesth. 2006;96:722-726.
6. Erdurmus M, Aydin B, Usta B, Yagci R, Gozdemir M, Totan Y. Patient comfort and surgeon satisfaction during cataract surgery using topical anesthesia with or without dexmedetomidine sedation. Eur $J$ Ophthalmol. 2008;18:361-367.

7. Muttu S, Liu EH, Ang SB, Chew PT, Lee TL, Ti LK. Comparison of dexmedetomidine and midazolam sedation for cataract surgery under topical anesthesia. J Cataract Refract Surg. 2005;31:1845-1846.

8. Jaakola ML, Ali-Melkkilä T, Kanto J, Kallio A, Scheinin H, Scheinin M. Dexmedetomidine reduces intraocular pressure, intubation responses, and anaesthetic requirements in patients undergoing ophthalmic surgery. Br J Anaesth. 1992;68:570-575.

9. Lee YY, Wong SM, Hung CT. Dexmedetomidine infusion as a supplement to isoflurane anaesthesia for vitreoretinal surgery. Br J Anaesth. 2007;98:47-483.

10. Ramsay MA, Savege TM, Simpson BR, Goodwin R. Controlled sedation with alphaxalone-alphadolone. Br Med J. 1974;22(5920):656-659.

11. Abdalla MI, Al Mansouri F, Bener A. Dexmedetomidine during local anesthesia. J Anesth. 2006;20:54-56.
Clinical Ophthalmology

\section{Publish your work in this journal}

Clinical Ophthalmology is an international, peer-reviewed journal covering all subspecialties within ophthalmology. Key topics include: Optometry; Visual science; Pharmacology and drug therapy in eye diseases; Basic Sciences; Primary and Secondary eye care; Patien Safety and Quality of Care Improvements. This journal is indexed on

Submit your manuscript here: http://www.dovepress.com/clinical-ophthalmology-journal

\section{Dovepress}

PubMed Central and CAS, and is the official journal of The Society of Clinical Ophthalmology (SCO). The manuscript management system is completely online and includes a very quick and fair peer-review system, which is all easy to use. Visit http://www.dovepress.com/ testimonials.php to read real quotes from published authors. 